\title{
UJI EFEKTIVITAS EKSTRAK BUAH BENGKUANG (Pachyrhizus erosus (L.) Urb.) SEBAGAI PENGAWET ALAMI CABAI MERAH (Capsicum annuum $\mathrm{L}$ )
}

\section{The Effectiveness Test of Jicama (Pachyrhizuserosus (L.)Urb.) Extract as a Natural Preservative for Red Chili (Capsicum annuum L)}

\author{
*Citra Larasari, Baharuddin Hamzah, dan Suherman \\ Pendidikan Kimia/FKIP - Universitas Tadulako, Palu - Indonesia 94118 \\ Received 03 June 2016, Revised 05 July 2016, Accepted 05 August 2016
}

\begin{abstract}
Red chili is one of the food susceptible to decay. It caused by its high water content and so it causes to keep power of red chili abbreviated. Jicama (Pachyrizuserosus (L.) Urb.) can act as a natural preservative for red chili due to the saponin compounds contained there in. This study aimed to prove the use of jicama extract as a natural preservative for red chili and to determine the most effective concentration of jicama extract as a natural preservative. The methods used in this study were a maceration to prepare the extract of jicama, and an iodimetric titration to determine the levels of vitamin $C$ before and after curing. The results showed that jicama extract can be used as a natural preservative for red chili. The most effective concentration of jicama extract in preserving the red chili was $4 \%$ with preservation durability of red chili for 14 days in which the smallest level of vitamin $C$ decreased among other concentrations, i.e. from $84.47 \mathrm{mg} / 100 \mathrm{~g}$ to $75.13 \mathrm{mg} / 100 \mathrm{~g}$ of material.
\end{abstract}

Keywords: Jicama (pachyrhizuserosus (L.) Urb.), preservation, red chili, vitamin C level.

\section{Pendahuluan}

Bahan pangan merupakan salah satu kebutuhan pokok bagi manusia, yang akan terus meningkat sesuai dengan laju pertumbuhan penduduk. Demikian pula laju produksi buah hortikultura tersebut, namun terjadi pasang surut. Selain itu, bahan pangan tersebut mudah mengalami perubahan fisik yang tidak diinginkan seperti pembusukan. Kerusakan bahan pangan ini umumnya disebabkan oleh mikroorganisme melalui proses enzimatis dan oksidasi, terutama yang mengandung protein dan lemak. Kerusakan tersebut perlu dihambat dengan cara pengawetan menggunakan pengawet dan antioksidan sintesis seperti formalin, asam benzoat, BHA (butylated hydroxyanisol), BHT (butylated hidroxytoluene) dan TBHA (tertier butylated hidroxyanisol) (Tranggono, 1990).

Diantara berbagai macam produk hortikultura yang ada di Indonesia, cabai merah merupakan tanaman sayur yang memerlukan proses pengawetan untuk

*Correspondence:

Citra Larasari

Program Studi Pendidikan Kimia, Fakultas Keguruan dan

IImu Pendidikan, Universitas Tadulako

email: citralarasari13@gmail.com

Published by Universitas Tadulako 2016 mencegah proses pembusukan. Cabai merah mengandung vitamin $\mathrm{C}$ (asam askorbat) dan beta karoten yang tinggi mengungguli buahbuahan yang sering dikonsumsi masyarakat seperti pepaya, mangga, nanas dan semangka. Vitamin C pada cabai merah berfungsi sebagai pemeliharaan membran sel, meningkatkan daya tahan terhadap infeksi dan mempercepat penyembuhan (Almatsier, 2004).

Cabai merah memiliki daya simpan yang sangat rendah karena mudah mengalami pembusukan dan produksi cabai merah tiap tahun tidak semua dikonsumsi oleh konsumen sehingga terjadi kelimpahan yang menimbulkan pembusukan pascapanen yang menyebabkan petani mengalami kerugian. Penyebab utama dari kerusakan cabai merah adalah karena kadar airnya yang tinggi, sehingga akan memperbesar terjadinya kerusakankerusakan fisiologis, mekanis, maupun aktivitas mikroorganisme. Mikroorganisme yang banyak menyebabkan kerusakan/pembusukan pada cabai merah adalah jamur. Untuk mencegah pembusukannya, cabai merah harus diawetkan dengan menggunakan bahan pengawet (Oktoviana, dkk., 2012). 
Penanganan pascapanen cabai merah di Indonesia umumnya masih sederhana sehingga tingkat kerusakannya sangat tinggi. Hal ini terjadi karena fasilitas dan pengetahuan petani tentang penanganan pascapanen masih terbatas. Teknologi pascapanen atau pengolahan cabai menjadi andalan dalam mempertahankan dan meningkatkan nilai jual produk yang dituntut efektif oleh konsumen. Oleh karena itu, petani cabai perlu memiliki pengetahuan tentang penanganan bahan pangan yang mudah rusak agar kesegarannya dapat dipertahankan lebih lama. Beberapa hasil penelitian menunjukkan cabai tergolong sayuran yang mudah rusak dan sulit dipertahankan dalam bentuk segar (Taufik, 2011).

Secara deduktif salah satu bahan yang dapat dijadikan sebagai pengawet alami adalah buah bengkuang. Buah bengkuang bukanlah hal yang baru bagi masyarakat Indonesia. Hampir setiap wilayah di Indonesia terdapat sentra-sentra tanaman bengkuang. Tanaman tersebut banyak digunakan sebagai tanaman sayuran. Pada saat musim panen produksi tanaman tersebut sangat melimpah dan tidak habis dikonsumsi oleh masyarakat. Karena itu sebagian besar mengalami kerusakan (pembusukan) (Moeksin \& Fransisca, 2010). Buah bengkuang biasanya hidup di daerah tropis dan sub-tropis serta memiliki potensi yang tinggi untuk dibudidayakan (Buckman, dkk., 2014).

Mikroorganisme dapat mencemari makanan dan menimbulkan perubahanperubahan kimiawi di dalamnya. Karena itu, adanya prosedur untuk mengendalikan pertumbuhan dan kontaminasi oleh mikroba merupakan suatu keharusan. Pengendalian ialah segala kegiatan yang dapat menghambat, membasmi atau menyingkirkan organisme (Lasandang, 2005). Banyak faktor dan keadaan yang dapat mempengaruhi penghambatan atau pembasmian mikroorganisme oleh bahan atau proses antimikrobial. Setiap spesies mikroorganisme menunjukkan kerentanan yang berbeda terhadap sarana fisik dan bahan kimia (Pelczar \& Chan, 1998).

Buah bengkuang mengandung beberapa senyawa kimia yang memiliki manfaat yang sangat baik yaitu vitamin $\mathrm{C}$, flavonoid dan saponin (Lukitaningsih, 2009). Sandler (2005) juga menyebutkan bahwa bengkuang mengandung senyawa saponin. Saponin merupakan salah satu metabolit sekunder yang mempunyai aktivitas biologi, diantaranya bersifat sebagai antimikroba. Di Indonesia, bengkuang telah banyak digunakan sebagai salah satu bahan kosmetik, terutama sebagai skrining matahari dan bahan pemutih kulit (Lukitaningsih, dkk., 2013) . Buah bengkuang juga dapat digunakan sebagai bahan pangan. Namun, tak banyak yang tahu bahwa kandungan saponin yang terkandung di dalamnya dapat dimanfaatkan sebagai bahan pembuatan pengawet alami pada tanaman sayur, seperti cabai merah (Irwan, dkk., 2007). Senyawa saponin merupakan larutan berbuih yang diklasifikasikan berdasarkan struktur aglycon ke dalam triterpenoid dan steroid saponin. Senyawa saponin mampu berperan sebagai pengawet alami karena dapat bekerja sebagai antimikroba yang akan merusak membran sitoplasma (Gotawa, dkk., 1999).

Tulisan ini dimaksudkan untuk menginvestigasi ekstrak buah bengkuang dalam mempertahankan tekstur, warna dan kandungan vitamin $\mathrm{C}$ di dalam cabai merah.

\section{METODE \\ Alat dan Bahan}

Peralatan yang digunakan pada penelitian ini adalah oven, blender, baskom, tabung reaksi, neraca digital, erlenmeyer $1000 \mathrm{~mL}$, shaker, gelas ukur $250 \mathrm{~mL}$ dan $10 \mathrm{~mL}$, labu ukur 100 $\mathrm{mL}$, pipet tetes, corong, kertas saring, vacuum pump, rotary evaporator, botol kecil, keranjang kecil, spatula, batang pengaduk, buret $25 \mathrm{~mL}$, klem dan statif, serta gelas kimia $100 \mathrm{~mL}$ dan $1000 \mathrm{~mL}$. Sedangkan bahan yang digunakan adalah buah bengkuang, cabai merah, etanol (Merck), larutan $\mathrm{HCl} 2 \mathrm{~N}$ (J.T Baker), larutan amilum 1\% (Merck), larutan standar iodine $0,01 \mathrm{~N}$ (Ajax chemicals), alumunium foil dan aquades.

\section{Cara Kerja}

Proses pembuatan ekstrak buah bengkuang dilakukan dengan mencuci buah bengkuang hingga bersih, memotong buah menjadi kecil dan mengeringkannya menggunakan oven pada suhu $60^{\circ} \mathrm{C}$ selama 2 hari. Kemudian buah dihaluskan menggunakan blender dan ditimbang sebanyak 200 gram. Selanjutnya, dilakukan uji busa saponin dengan cara 0,5 gram simplisia dimasukkan ke dalam tabung reaksi yang telah berisikan $10 \mathrm{~mL}$ aquades, dikocok dan ditambah 1 tetes larutan $\mathrm{HCl}$ 2 N. Setelah itu, dimaserasi selama $3 \times 24$ jam dengan menggunakan $600 \mathrm{~mL}$ pelarut etanol. Kemudian, ekstrak dievaporasi dengan menggunakan rotary evaporator pada suhu $50{ }^{\circ} \mathrm{C}$ dengan kecepatan $8 \mathrm{rpm}$. Selanjutnya, ekstrak kental yang diperoleh dimasukkan ke dalam oven pada suhu $30^{\circ} \mathrm{C}$ sampai $40^{\circ} \mathrm{C}$. 
Setelah itu, dibuat larutan ekstrak dengan konsentrasi $0 \%, 2 \%, 4 \%$, dan 6\%.

Pengawetan cabai merah dilakukan dengan cara cabai merah dicelupkan ke dalam larutan ekstrak selama 5 detik dan dibiarkan selama beberapa hari. Parameter yang diamati adalah perubahan tekstur, warna dan kadar vitamin $\mathrm{C}$ sebelum dan sesudah pengawetan. Penentuan kadar vitamin $\mathrm{C}$ dilakukan dengan cara cabai merah ditimbang sebanyak 100 gram dan dihaluskan dengan menggunakan blender. Selanjutnya, diambil sebanyak 20 gram sluri dan diencerkan hingga 100 mL. Kemudian, larutan disaring hingga diperoleh filtrat cabai merah. Selanjutnya, dimasukkan $25 \mathrm{~mL}$ filtrat, $20 \mathrm{~mL}$ aquades dan $2 \mathrm{~mL}$ amilum 1\% ke dalam erlenmeyer. Setelah itu, dilakukan titrasi dengan menggunakan larutan standar iodine $0,01 \mathrm{~N}$ sebagai titrannya.

\section{Hasil dan Pembahasan}

Penelitian ini dilakukan untuk membuktikan apakah ekstrak buah bengkuang dapat dijadikan sebagai pengawet alami cabai merah dan menentukan konsentrasi efektif dari ekstrak buah bengkuang yang dapat mempertahankan cabai merah lebih lama. Metode yang digunakan dalam penelitian ini adalah maserasi untuk pembuatan ekstrak dan titrasi iodometri untuk menentukan kadar vitamin $\mathrm{C}$ sebelum dan sesudah pengawetan.

\section{Ekstrak Bengkuang yang Diperoleh}

Pada proses pembuatan ekstrak buah bengkuang, hasil yang diperoleh adalah ekstrak kering seberat 15,3 gram dari 100 gram bahan. Dimana, dari ekstrak kering tersebut, dibuat 4 jenis konsentrasi yakni $0 \%, 2 \%, 4 \%$ dan $6 \%$ yang digunakan untuk mengawetkan cabai merah. Pada tiap konsentrasi, digunakan sebanyak 16 buah cabai untuk diuji efektivitas tiap konsentrasi yang telah dibuat. Sehingga, selama proses pengawetan, hasil yang diperoleh menunjukkan perbedaan pada tiap-tiap konsentrasi.

\section{Lama Waktu Penyimpanan Cabai Merah Selanjutnya dilakukan proses pengawetan pada cabai, dan diperoleh pengamatan terhadap lama penyimpanan pada cabai merah yang berbeda-beda yaitu seperti pada Tabel 1 berikut:}

Tabel 1 Hasil Pengamatan Lama Penyimpanan Cabai Merah

\begin{tabular}{cc}
$\frac{\text { Konsentrasi }}{\text { Bengkuang (\%) }}$ & $\begin{array}{c}\text { Lama Penyimpanan } \\
\text { (hari) }\end{array}$ \\
\hline 0 & 9 \\
2 & 11 \\
4 & 14 \\
6 & 16 \\
\hline
\end{tabular}

Selama proses pengawetan, ternyata setiap cabai memiliki lama masa penyimpanan yang berbeda untuk tiap konsentrasi ekstrak. Dimana semakin besar konsentrasi ekstrak yang digunakan untuk mengawetkan cabai merah, maka cabai tersebut memiliki masa simpan yang lebih lama.Adapun cabai yang diawetkan menggunakan ekstrak 2\% memiliki masa simpan atau daya tahan selama 11 hari, lebih lama 2 hari dibandingkan kontrol. Untuk ekstrak 4\% memiliki masa simpan selama 14 hari dan ekstrak $6 \%$ mampu membuat cabai memiliki masa simpan hingga 16 hari. Hal ini menunjukkan bahwa ekstrak buah bengkuang dapat menghambat laju pembusukan pada cabai merah.

\section{Pengamatan Mutu Cabai Merah}

Berdasarkan hasil pengamatan terhadap mutu cabai baik tekstur dan warna selama proses pengawetan, diperoleh hasil seperti pada tabel berikut:

Tabel 2 Tekstur dan Warna Cabai Merah pada

\begin{tabular}{ccc} 
& \multicolumn{3}{c}{ Konsentrasi Ekstrak 0\% } \\
\hline Hari & \multicolumn{2}{c}{ Pengamatan Mutu } \\
\cline { 2 - 3 } ke- & Tekstur & Wama \\
\hline 1 & Semua baik & Semua merah \\
2 & Semua baik & $\frac{\text { Semua merah }}{\text { Semua merah }}$ \\
3 & Semua baik & 1 kecoklatan, 15 merah \\
4 & Semua baik & 1 kecoklatan, 2 merah tua, 13 \\
5 & 4 agak lembek, 12 baik & merah \\
& 4 lembek, 12 baik & 3 kecoklatan, 13 merah \\
6 & 4 lembek, 1 agak lembek, 11 baik & 4 kecoklatan, 12 merah \\
7 & 6 agak kering, 10 baik & 5 kecoklatan, 11 merah \\
8 & Semua agak kering & 4 kehitaman, 3 agak coklat, 9 \\
9 & & merah tua \\
\hline
\end{tabular}

Tabel 3 Tekstur dan Warna Cabai Merah pada Konsentrasi Ekstrak 2\%

\begin{tabular}{ccc}
\hline & \multicolumn{2}{c}{ Pengamatam Mutu } \\
\cline { 2 - 3 } ke- & Tekstur & Warna \\
\hline 1 & Semua baik & Semua merah \\
2 & Semua baik & Semua merah \\
3 & Semua baik & Semua merah \\
4 & Semua baik & Semua merah \\
5 & 2 agak lembek, 14 baik & 2 agak kecoklatan, 14 merah \\
6 & 2 agak lembek, 14 baik & 2 kecoklatan, 14 merah \\
7 & 3 lembek, 13 baik & 2 kecoklatan, 14 merah tua \\
8 & 4 lembek, 12 agak kering & 2 kecoklatan, 1 agak kuning. \\
& & 13 merah \\
9 & Semua agak kering & 4 kecoklatan, 10 merah tua \\
10 & Semua kering & 5 kecoklatan, 11 merah tua \\
11 & Semua kering & 5 kecoklatan, 11 merah tua \\
\hline
\end{tabular}


Tabel 4 Tekstur dan Warna Cabai Merah pada Konsentrasi Ekstrak 4\%

\begin{tabular}{|c|c|c|}
\hline \multirow{2}{*}{$\begin{array}{l}\text { Hari } \\
\text { ke }\end{array}$} & \multicolumn{2}{|c|}{ Pengamatan Mutu } \\
\hline & Tekstü & Warna \\
\hline 1 & Semua baik & Semua merah \\
\hline 2 & Semua baik & Semua meralı \\
\hline 3 & Semaua baik & Semua merah \\
\hline 4 & Semuna baik & Semua merah \\
\hline 5 & Semua baik & Semua merah \\
\hline 6 & Semua baik & Semua merah \\
\hline 7 & 1 lembek, 15 cukup baik & 1 merah kecoklatan, 15 merah \\
\hline 8 & 2 lembek, 14 cukup bsik & 2 merah kecoklatan, 14 merah \\
\hline 9 & Semü agak lembek & 3 kecoklatan. 13 merah tua \\
\hline 10 & Semua lembek & 3 kecoklatan, 13 merah tua \\
\hline 11 & Semua lembek. & 4 kecoklatan, 12 merah tua \\
\hline 12 & Senua agak kering & 4 kecoklatun. 12 merah tha \\
\hline 13 & Semux kering & 6 kecoklatan. 10 merah tua \\
\hline 14 & Semua kering & 7 kecoklatan, 9 merah tea \\
\hline
\end{tabular}

Tabel 5 Tekstur dan Warna Cabai Merah pada Konsentrasi Ekstrak 6\%

\begin{tabular}{|c|c|c|}
\hline \multirow{2}{*}{$\begin{array}{l}\text { Hani } \\
\text { ke- }\end{array}$} & \multicolumn{2}{|c|}{ Pengamatan Mutu } \\
\hline & Tekstur & Wama \\
\hline 1 & Semua baik & Semua merah \\
\hline 2 & Semua baik & Semua merah \\
\hline 3 & Senzua baik & Semua merah \\
\hline 4 & Semua baik & Semua merah \\
\hline 5 & Semua baik & Semua merah \\
\hline 6 & Senuua baik & Semua merah \\
\hline 7 & Semua baik & Semua merah \\
\hline 8 & 1 lembek, 15 baik & 1 merah tha. 15 merah \\
\hline 9 & 2 lembek, 14 baik & 2 merah kecoklatan. 14 merah tua \\
\hline 10 & 2 lembek, 14 agak kering & 2 merah kecoklatan, 14 merah tua \\
\hline 11 & Semua agak kering & 2 merah kecoklatan. 14 merah nua \\
\hline 12 & Semu agak kering & 3 merah kecolkatan, 13 merah tou \\
\hline 13 & 5 kering, 11 agak kering & 5 merah kecoklatan, 11 merah tua \\
\hline 14 & 5 kering, 11 agak kering & 5 merah kecoklatan. 11 merah tha \\
\hline 15 & Semma kering & 5 merah kecoklatan. 11 merah ta \\
\hline 16 & Semua kering & 5 merah kecoklatan, 11 merah tua \\
\hline
\end{tabular}

Berdasarkan hasil pengawetan yang dilakukan menggunakan ekstrak bengkuang, menunjukkan bahwa semakin lama cabai tersebut disimpan, maka akan terjadi perubahan tekstur menjadi agak lembek dan kemudian mengering. Perubahan ini disebabkan oleh penguraian zat-zat organik yang terkandung dalam cabai pada proses metabolisme. Pengawetan dapat menghambat kerusakan pada bahan pangan karena cepat atau lambat akan mengalami kerusakan. Bahan pangan yang telah diawetkan dapat mengalami perubahan tetapi tidak terlihat langsung karena terjadi sangat lambat (Oktoviana, dkk., 2012). Penyebab utama dari kerusakan cabai merah adalah karena kadar airnya yang tinggi, sehingga akan memperbesar terjadinya kerusakankerusakan fisiologis, mekanis, maupun aktivitas mikroorganisme. Mikroorganisme yang banyak menyebabkan kerusakan/pembusukan pada cabai merah adalah jamur (Oktoviana, dkk., 2012).

Cabai merah termasuk jenis sayuran buah dengan warna yang khas merah menarikserta mempunyai rasa pedas yang merangsang. Cabai merah merupakan komoditi sayuran yang mempunyai nilai ekonomi tinggi dan sangat penting baik pada pasaran dalam negerimaupun luar negeri. Semakin lama waktu pengawetan, maka warna cabaipun menjadi agak kecoklatan. Hal ini terjadi pada cabai di semua konsentrasi. Hanya saja, perubahan warna tersebut memiliki rentang waktu yang berbeda.

\section{Kadar Vitamin $C$}

Sampel cabai merah yang diawetkan juga ditentukan kadar vitamin C-nya, baik sebelum proses pengawetan maupun setelah dilakukan pengawetan. Hasil yang diperoleh memiliki perbedaan pada cabai merah di masing-masing konsentrasi ekstrak. Kadar vitamin C yang diperoleh tersebut seperti pada Tabel 6 berikut.

Tabel 6 Kadar Vitamin C Cabai Merah

Sebelum dan Sesudah Pengawetan

\begin{tabular}{|c|c|c|c|c|}
\hline \multirow{4}{*}{$\frac{\text { Sampel cabai }}{\text { merahi }}$} & \multicolumn{2}{|c|}{ Kadar vitamin $\mathrm{C}$} & \multicolumn{2}{|c|}{ Persentase kadu vitamin C } \\
\hline & Sschelum & Sesudah & Yang & Yang \\
\hline & pengawetan & pengawetan & berkurang & dipertahankan \\
\hline & (mg) & (mg) & (\%) & (\%) \\
\hline $0 \%$ & 84,47 & 36,40 & 56,91 & 43,09 \\
\hline $2 \%$ & 84,47 & 68,00 & 19,50 & 80,50 \\
\hline $4 \%$ & 84,47 & 75,13 & 11,06 & 88.94 \\
\hline $6 \%$ & 84,47 & 59.27 & 29.83 & 70,17 \\
\hline
\end{tabular}

Cabai merah memiliki beberapa kandungan vitamin, salah satunya adalah vitamin C. Pada umumnya buah merupakan sumber vitamin C yang penting, sehingga stabilitas vitamin $C$ dalam pengolahan dan penyimpanan buah serta hasil pengolahannya merupakan masalah yang paling penting diperhatikan. Dalam pengolahan dan penyimpanan sering terjadi kehilangan kandungan vitamin $\mathrm{C}$ karena vitamin $\mathrm{C}$ tidak tahan terhadap panas dan mudah teroksidasi (Hulme, 1997). Cabai tidak dapat lama disimpan dalam keadaan segar karena buah cabai merupakan struktur hidup yang setelah dipanen mudah mengalami perubahan fisik maupun perubahan kimia misalnya perubahan struktur, perubahan warna, dan perubahan vitamin C (Oktoviana, dkk., 2012).

Hasil penentuan kadar vitamin C pada tiap konsentrasi setelah proses pengawetan menggunakan metode titrasi iodometri dibuat dalam kurva seperti pada Gambar 1 berikut: 


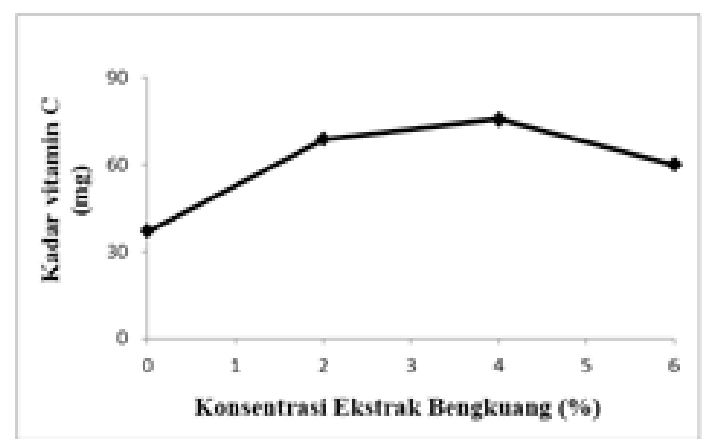

Gambar 1 Hubungan konsentrasi ekstrak bengkuang dengan kadar vitamin $\mathrm{C}$ cabai merah

Berdasarkan faktor tekstur, warna dan kualitas cabai merah yang digunakan sama, sehingga pada penentuan kadar vitamin C sebelum proses pengawetan diasumsikan bahwa kadar vitamin C-nya sama. Oleh karena itu untuk semua konsentrasi, kadar vitamin $C$ pada cabai diperoleh sebesar 84,47 $\mathrm{mg} / 100$ g. Berbeda ketika setelah adanya proses pengawetan dengan lama masa simpan yang berbeda-beda pada tiap konsentrasi. Berdasarkan Gambar 1 tersebut, untuk 0\% kadar vitamin C berkurang menjadi 36,40 $\mathrm{mg} / 100 \mathrm{~g}$. Untuk konsentrasi $2 \%$ berkurang menjadi $68,00 \mathrm{mg} / 100 \mathrm{~g}$, untuk $4 \%$ berkurang menjadi $75,13 \mathrm{mg} / 100 \mathrm{~g}$ dan $6 \%$ berkurang menjadi 59,27 mg/100 g. Berdasarkan data tersebut, terlihat bahwa yang paling sedikit mengalami penurunan kadar vitamin $\mathrm{C}$ yaitu cabai yang diawetkan menggunakan ekstrak $4 \%$, walaupun masa simpannya hanya bertahan selama 14 hari.

Perubahan kadar vitamin C dari 4 konsentrasi ekstrak tersebut dikarenakan cabai merah dengan konsentrasi $4 \%$ dipengaruhi oleh tingginya konsentrasi ekstrak yang memiliki peran dalam mengawetkan cabai. Sehingga hal itulah yang menyababkan kadar vitamin C-nya masih cukup tinggi. Sedangkan pada cabai merah dengan konsentrasi 6\% mengalami penurunan namun lebih tahan lama karena yang berperan adalah lama waktu penyimpanannya.

Pengaruh lama penyimpanan terhadap kandungan vitamin $\mathrm{C}$ tidak berbeda nyata, akan tetapi cenderung mengalami penurunan. Hal ini disebabkan karena tertundanya penguapan air yang menyebabkan struktur sel yang semula utuh menjadi layu.Dimana enzim askorbat oksidase tidak dibebaskan oleh sel sehingga tidak mampu mengoksidasi vitamin $\mathrm{C}$ lebih lanjut menjadi senyawa yang tidak mempunyai aktivitas vitamin C lagi. Tetapi apabila sel mengalami kelayuan maka vitamin $\mathrm{C}$ mengalami kerusakan (Gaman \& Sherrington, 1992).

\section{Kesimpulan}

Ekstrak buah bengkuang dapat digunakan sebagai pengawet alami pada cabai merah, karena dapat menghambat aktivitas dari mikroorganisme sehingga laju pembusukan pada cabai merah dapat berkurang. Ekstrak buah bengkuang yang paling efektif untuk mengawetkan cabai merah adalah pada konsentrasi 4\% yaitu selama 14 hari dengan kadar vitamin $\mathrm{C}$ setelah diawetkan yaitu 75,13 $\mathrm{mg} / 100 \mathrm{~g}$ dari kadar awal yaitu $84,47 \mathrm{mg} / 100$ g. Dimana, ini merupakan penurunan kadar vitamin $\mathrm{C}$ yang paling kecil dari konsentrasi lainnya.

\section{Ucapan Terima Kasih}

Penulis mengucapkan terima kasih kepada kepala laboran laboratorium Agroteknologi FAPERTA dan semua pihak yang telah membantu dalam pelaksanaan penelitian ini.

\section{Referensi}

Almatsier, S. (2004). Prinsip dasar ilmu gizi. Jakarta: Gramedia Pustaka Umum.

Buckman, E. S., Plahar, W. A., Oduro, I. N., \& Carey, E. E. (2014). Effect of sodium metabisulphite and blanching pretreatments on the quality characteristics of yam bean (pachyrizhus erosus) flour. British Journal of Applied Science \& Technology, 6(2), 138-144.

Gaman, P. M., \& Sherrington, K. B. (1992). Ilmu pangan, pengantar ilmu pangan, nutrisi dan mikrobiologi. Yogyakarta: Universitas Gajah Mada.

Gotawa, I., Sugiarto, S., Nurhadi, M., Widiyastuti, Y., Wahyono, S., \& Prapti, I. (1999). Inventaris tanaman obat indonesia jilid $V$. Jakarta: Departemen Kesehatan Badan Penelitian dan Pengembangan Kesehatan.

Hulme, A. C. (1997). The biochemistry of fruit and their products (2nd ed.). London: Academics Press.

Irwan, A., Komari, N., \& Rusdiana. (2007). Uji aktifitas ekstrak saponin fraksi n-butanol dari kulit batang kemiri (aleurites moluccana willd) pada larva nyamuk aedes aegypti. Jurnal Sains dan Terapan Kimia, 1(2), 93-101. 
Lasandang, B. (2005). Uji daya antibakteri ekstrak biji srikaya (annona squamosa linn.) terhadap salmonella typhi dan vibrio cholerae. (Skripsi), FKIP Universitas Tadulako, Tidak diterbitkan.

Lukitaningsih, E. (2009). The exploration of whitening and sun screening compounds in bengkoang roots (pachyrhizus erosus). (Disertation), Würzburg University, Germany.

Lukitaningsih, E., Bahi, M., \& Holzgrabe, U. (2013). Tyrosinase inhibition type of isolated compounds obtained from pachyrhizus erosus. Aceh International Journal of Science and Technology, 2(3), 98-102.

Moeksin, R., \& Fransisca, R. (2010). Pembuatan etanol dari bengkuang dengan variasi berat ragi, waktu dan jenis ragi Jurnal Teknik Kimia, 17(2), 25-30.
Oktoviana, Y., Aminah, S., \& Sakung, J. (2012). Pengaruh lama penyimpanan dan konsentrasi natrium benzoat terhadap kadar vitamin $\mathrm{C}$ cabai merah (capsicum annuum 1) Jurnal Akademika Kimia, 1(4), 193-199.

Pelczar, M. J., \& Chan, E. C. S. (1998). Dasardasar mikrobiologi 2 Jakarta: Universitas Indonesia Press.

Sandler, J. A. (2005). The phytochemical extraction and analysis of new flavonoids and saponins from the genus silphium. (Dissertation), The University of Texas at Austin.

Taufik, M. (2011). Analisis pendapat usaha tani dan penanganan pascapanen cabai merah. Jurnal Litbang Pertanian, 30(2), 66-72.

Tranggono. (1990). Bahan tambahan pangan (food additive). Yogyakarta: Pusat Antar Universitas Pangan dan Gizi. 